\title{
Development, embryonic genome activity and mitochondrial characteristics of bovine-pig inter-family nuclear transfer embryos
}

\author{
Irina Lagutina ${ }^{1}$, Helena Fulka ${ }^{2}$, Tiziana A L Brevini ${ }^{3}$, Stefania Antonini ${ }^{3}$, Dario Brunetti ${ }^{1}$, \\ Silvia Colleoni ${ }^{1}$, Fulvio Gandolfi ${ }^{3}$, Giovanna Lazzari ${ }^{1}$, Josef Fulka Jr$^{2}$ and Cesare Galli ${ }^{1,4}$ \\ ${ }^{1}$ Laboratorio di Tecnologie della Riproduzione, Avantea srl, Via Porcellasco 7/f, 26100 Cremona, Italy, ${ }^{2}$ Institute of \\ Animal Science, Pratelstvi 815, PO Box 1, 10401 Prague 114, Czech Republic, ${ }^{3}$ Biomedical Embryology Unit, \\ Department of Animal Science, University of Milan, 20133 Milan, Italy and ${ }^{4}$ Dipartimento Clinico Veterinario, \\ Università di Bologna, 40064 Bologna, Italy
}

Correspondence should be addressed to I Lagutina; Email: irinalagutina@avantea.it

\begin{abstract}
The best results of inter-species somatic cell nuclear transfer (iSCNT) in mammals were obtained using closely related species that can hybridise naturally. However, in the last years, many reports describing blastocyst development following iSCNT between species with distant taxonomical relations (inter-classes, inter-order and inter-family) have been published. This indicates that embryonic genome activation (EGA) in xeno-cytoplasm is possible, albeit very rarely. Using a bovine-pig (inter-family) iSCNT model, we studied the basic characteristics of EGA: expression and activity of RNA polymerase II (RNA Pol II), formation of nucleoli (as an indicator of RNA polymerase I (RNA Pol I) activity), expression of the key pluripotency gene NANOG and alteration of mitochondrial mass. In control embryos (obtained by IVF or iSCNT), EGA was characterised by RNA Pol II accumulation and massive production of poly-adenylated transcripts (detected with oligo dT probes) in blastomere nuclei, and formation of nucleoli as a result of RNA Pol I activity. Conversely, iSCNT embryos were characterised by the absence of accumulation and low activity of RNA Pol II and inability to form active mature nucleoli. Moreover, in iSCNT embryos, NANOG was not expressed, and mitochondria mass was significantly lower than in intra-species embryos. Finally, the complete developmental block at the 16-25-cell stage for pig-bovine iSCNT embryos and at the four-cell stage for bovine-pig iSCNT embryos strongly suggests that EGA is not taking place in iSCNT embryos. Thus, our experiments clearly demonstrate poor nucleus-cytoplasm compatibility between these animal species.

Reproduction (2010) $\mathbf{1 4 0} 273-285$
\end{abstract}

\section{Introduction}

During early embryogenesis, a precise and accurate communication between nucleus and cytoplasm determines the success of such critical step of embryo development as embryonic genome activation (EGA). In inter-species somatic cell nuclear transfer (iSCNT), the situation is even more complicated as the donor nucleus and recipient cytoplasm originate from different species. Thus, during the maternal-to-embryonic transition (MET), activation of embryonic nuclei, which bear the genetic information of one species, critically depends on the stock of proteins and transcripts in the recipient cytoplasm (Schultz 1993, Minami et al. 2007), which is derived from another species. Initiation of gene transcription involves many factors, and the absence or the species incompatibility of just one of them can block the subsequent transcription (Heix et al. 1997).
Nevertheless, despite the possibility of nucleuscytoplasm incompatibility, iSCNT represents a plausible experimental scheme especially when oocytes are extremely scarce. In 1999, the work by Dominko et al. (1999) raised hopes about the possibility of using oocytes from different species as recipients of somatic cell nuclei to save endangered species or to create embryonic stem cells for human cell therapy. Species that hybridise naturally are more likely to perform well in iSCNT experiments. This is understandable, since the natural production of living hybrid offspring shows that a certain nuclear-cytoplasmic compatibility exists between the two species (Mastromonaco et al. 2007). As a rule, iSCNT in mammals is more efficient when donor and recipient cells are from closely related species. For instance, inter-subspecies SCNT produced healthy offspring of Boer goat (Jian-Quan et al. 2007) and grey wolf (Kim et al. 2007). iSCNT embryos derived 
from mouflon (Ovis orientalis musimon), nucleus donor cells and sheep (Ovis aries) oocytes (Loi et al. 2001) could also develop to term. Wildcat (Felis silvestris lybica; Gomez et al. 2004) and sand cat (Felis margarita; Gomez et al. 2008) were produced using domestic cat (Felis catus) oocytes. iSCNT embryos derived from gaur (Bos gaurus) adult nucleus donor cells and bovine (Bos taurus) oocytes implanted and foetuses developed up to 200 days (Lanza et al. 2000). Inter-genus SCNT embryos derived from leopard cat (Prionailurus bengalensis) nucleus donor cells, and domestic cat oocytes were able to implant and form foetuses (Yin et al. 2006).

On the other hand, many studies have reported production of iSCNT morulae and blastocysts (BL) also when nucleus donor cells and recipient oocytes had a very distant taxonomical relation, like in the case of inter-family bovine-pig (Dominko et al. 1999, Uhm et al. 2007), inter-order cat- and panda-rabbit (Wen et al. 2005), camel- and Tibetan antelope-rabbit (Zhao et al. 2006), human-rabbit (Shi et al. 2008), dog-pig (Sugimura et al. 2009), tiger-pig (Hashem et al. 2007), human-bovine (Chang et al. 2003, Illmensee et al. 2006, Li et al. 2008) or inter-classes chicken-rabbit (Liu et al. 2004) combinations. However, this approach remains ineffective.

The aim of the present study was to investigate preimplantation development in bovine-pig iSCNT embryos that have been previously shown to develop to blastocyst stage at the rate of $4 \%$ (Uhm et al. 2007) to $8 \%$ (Dominko et al. 1999). Indeed, very few data are available on embryonic gene function before and at the time of EGA in iSCNT embryos (Arat et al. 2003, Bjerregaard et al. 2007, Chung et al. 2009, Hamilton et al. 2004, Kim et al. 2004, Li et al. 2008, Wang et al. 2009), and all show abnormal genome activation and gene expression profiles in the iSCNT embryos studied. It is likely that the ineffectiveness of the iSCNT approach may be linked to abnormal (or absence of) EGA in such embryos due to aberrant nucleuscytoplasm cross-talk. Since Bos taurus and Sus scrofa domesticus have a rather distant (inter-family) taxonomical relation and EGA occurs at different cell stages (8-16-cell stage in bovine and four-cell stage in porcine embryos), the pig-bovine iSCNT model may thus represent a useful model for investigating the nucleus-cytoplasm interaction during early embryo development. We have focused especially on nucleus remodelling, embryo development, donor cell-specific gene (collagen type $\mathrm{VI} \propto 1$ gene $(C O L 6 A 1))$ fate and EGA during MET, with special attention to RNA polymerase II (RNA Pol II) activity, nucleoli formation (as an indicator of RNA polymerase I (RNA Pol I) activity) and activation of the pluripotency gene NANOG. Finally, we have investigated the behaviour of mitochondria under xeno-nuclear control.

\section{Results}

\section{Nucleus remodelling in bovine and porcine ooplasm}

To investigate pre-implantation development, we created both intra-species (bovine or porcine NT) and inter-species (bovine-pig or pig-bovine iSCNT) embryos by NT. Remodelling is believed to be an essential event in reprogramming of the genetic material after NT. This phenomenon involves structural changes in the donor nucleus, such as nuclear envelope breakdown, premature chromosome condensation (PCC) as well as pronuclear development and swelling (Tsunoda et al. 1989). The analysis of NT and iSCNT embryos (Supplementary Table 1, see section on supplementary data given at the end of this article) showed that about $90-100 \%$ of fused embryos, irrespectively of the origin of the recipient cytoplasm and of the nucleus donor cell, exhibited PCC $1 \mathrm{~h}$ post-fusion and swollen nuclei with a pronucleus-like appearance $3 \mathrm{~h}$ after activation. These results indicate that remodelling of the donor cell nucleus in the recipient cytoplasm is highly efficient and not species specific.

\section{In vitro development of iSCNT embryos}

In the first set of experiments, we investigated the developmental potential of iSCNT embryos reconstructed from porcine donor cells and bovine recipient oocytes. As a control, intra-species porcine NT embryos were used. We tested two porcine adult cell lines (PAF1 and PAF2) and one foetal fibroblast line (PFF) as nucleus donors for both NT and iSCNT embryos. In the control group, the proportion of embryos which had developed to the blastocyst stage was $20-38 \%$ at day 6 postactivation (Supplementary Table 2, see section on supplementary data given at the end of this article). Conversely, iSCNT embryos did not develop beyond the 16-25-cell stage (72 h after activation), and eventually, development was blocked. There was no sign of compaction or blastulation during further culture till day 8. No difference between SOFaa and CR1aa medium in the ability to support the development of iSCNT embryos was found.

We then repeated the same experiments using bovine foetal (BFF) as well as adult male (BAFm) and female (BAFf) fibroblasts as nucleus donors and porcine oocytes as recipients. The proportion of control bovine NT embryos that developed to blastocyst stage was about $50 \%$ at day 7 indicating a high efficiency of bovine NT and the suitability of the donor cell lines used (Supplementary Table 3, see section on supplementary data given at the end of this article). At $72 \mathrm{~h}$ after activation, all advanced embryos were at the four-cell stage in both NT and iSCNT groups. However, at $96 \mathrm{~h}$, almost half $(47 \%, n=38)$ of control NT embryos possessed eight or more cells while all advanced iSCNT embryos (50-67.9\%) were blocked at the 4-6-cell 
stage (4.1 $\pm 0.2, n=30 ; 4-6$ nuclei) indicating developmental arrest. There was no sign of compaction or blastulation during further culture till day 7 .

Next, we counted the number of cells and nuclei in each pig-bovine iSCNT embryo because they just passed the porcine EGA stage. This step was necessary also as high level of cellular abnormality can be expected in iSCNT embryos and blastomere fragmentation can occur (Lorthongpanich et al. 2008). We analysed the most advanced embryos at $48 \mathrm{~h}$ (i.e. embryos made up of $\geq 4$ cells), $72 \mathrm{~h}$ ( $\geq 8$ cells) and $96 \mathrm{~h}$ ( $\geq 8$ cells) after activation. There was no difference in the number of cells $(10.2 \pm 2.1)$ and nuclei $(9.6 \pm 2.3)$ between bovine NT and pig-bovine iSCNT embryos at $48 \mathrm{~h}$. At $72 \mathrm{~h}$, the average number of nuclei in NT embryos (Table 1) was equal to cell number and was significantly lower than in pig-bovine iSCNT embryos. At the same time, the average number of nuclei in pig-bovine iSCNT embryos (Table 1) was significantly higher than the number of blastomeres because many binucleate blastomeres were observed (Supplementary Figure 1, see section on supplementary data given at the end of this article). Binucleate blastomeres were rarely seen in the control group (Table 1), whereas the average number of anucleate blastomeres, which is a marker of embryo fragmentation, was equal in NT and iSCNT embryos. DAPI staining of paraformaldehyde-fixed embryos also revealed a tremendous difference in nuclear morphology: in NT embryos, nuclei were stained homogeneously, whereas, in iSCNT embryos, many nuclei with condensed chromosomes were detected (Fig. 1). Since chromosome condensation can also occur during apoptosis and one of the earliest events in apoptosis is the translocation of phosphatidylserine to the outer membrane, we stained fixed embryos with Annexin V, which binds to phosphatidylserine, to detect apoptotic cells in embryos at $96 \mathrm{~h}$ post-activation. However, there was no difference in the apoptotic rate of NT and iSCNT embryos (data not shown). At 96 h, the number of nuclei in bovine NT embryos increased significantly, while it did not change in pig-bovine iSCNT embryos. This clearly indicates that development in iSCNT embryos was blocked.

Altogether these results suggest that in iSCNT embryos, early cleavage is governed by the cytoplasm of the recipient oocyte and by maternally inherited factors that engage in cell division. Porcine oocytes controlled the development of bovine-pig iSCNT embryos arresting them at the time of porcine MET (i.e. four-cell stage), whereas bovine oocytes blocked the development of pig-bovine iSCNT embryos at the time of bovine MET during the fourth cell cycle (8-16-cell stage).

\section{Cytoplasm controls the expression of fibroblast-specific COL6A1}

We then asked how nuclear genes with tissue-specific inducible promoters that should be active in the somatic donor cells but inactive in the oocyte recipients (Memili \& First 1998) behaved in iSCNT embryos. To this aim, we evaluated the expression of the fibroblast-specific COL6A1 (Supplementary Figure 5, see section on supplementary data given at the end of this article) in bovine NT and in pig-bovine iSCNT embryos starting from the two-cell stage. COL6A1 is highly expressed in bovine and porcine adult fibroblasts, and can be detected by RT-PCR from the equivalent of one fibroblast. COL6A1 mRNA was not detected in any of the embryos analysed, indicating that the bovine cytoplasm not only blocked de novo transcription of a fibroblast-specific gene irrespectively of the species affiliation of the nuclear donor but also effectively degraded transcripts inherited with the fibroblast cytoplasm. These preliminary experiments seem to confirm the data by $\mathrm{Li}$ et al. (2007) on the silencing of the fibroblast-specific vimentin and collagen genes in early yak-bovine iSCNT embryos.

Table 1 Number of cells and nuclei in bovine nuclear transfer (NT) and pig-bovine inter-species somatic cell nuclear transfer (iSCNT) embryos. Mean \pm S.D.

\begin{tabular}{|c|c|c|c|c|}
\hline \multirow[b]{3}{*}{ Parameters } & \multicolumn{4}{|c|}{ Time of in vitro culture } \\
\hline & \multicolumn{2}{|c|}{$72 \mathrm{~h}$} & \multicolumn{2}{|c|}{$96 \mathrm{~h}$} \\
\hline & NT & iSCNT & NT & iSCNT \\
\hline Number of embryos & 46 & 62 & 45 & 32 \\
\hline Number of cells/embryo & $8-17$ & $8-25$ & & \\
\hline Number of cells/embryo, $M \pm$ s.D. & $11.2 \pm 2.7^{\mathrm{a}}$ & $13.8 \pm 3.9^{\mathrm{bA}}$ & & \\
\hline $\begin{array}{l}\text { Number of nuclei/embryo, } \bar{M} \pm \text { s.D. } \\
\% \text { of embryos with: }\end{array}$ & $11.2 \pm 2.6^{\mathrm{a}}$ & $15 \pm \overline{4} .4^{\mathrm{bB}}$ & $19.7 \pm 7.2^{c}$ & $15.2 \pm 3.8^{b}$ \\
\hline Anucleate cells & 22.6 & 23.9 & & \\
\hline Binucleate cells & $10.3^{\mathrm{a}}$ & $47.3^{\mathrm{b}}$ & & \\
\hline$\geq 16$ cells & $4.3^{\mathrm{a}}$ & $12.9^{\mathrm{a}^{*}}$ & & \\
\hline$\geq 16$ nuclei & $2.2^{\mathrm{a}}$ & $30.6^{\mathrm{b}}$ & & \\
\hline
\end{tabular}

Values with different letters in one row $(\mathrm{a}, \mathrm{b}, \mathrm{c})$ are significantly different by $t$-test, $P<0.01$. Values with ' $\mathrm{a}$ ' versus ' $\mathrm{a}$ '” in one row describe a tendency to be different, $P=0.12$. Values with different letters in one column $(A, B)$ are significantly different, $P<0.01$. 


\section{Assessment of EGA}

\section{RNA Pol II}

Since the previous experiments indicate that iSCNT embryos' development is blocked at the time of EGA, we decided to analyse the events associated with the activation of transcription. In Xenopus laevis, EGA initiates with the activation of class II genes (mRNA), followed by class III genes (tRNA) and finally class I genes (rRNA; Shiokawa et al. 1989, 1994). In eukaryotes, RNA Pol II is responsible for transcription of mRNAs and of most of the small nuclear RNAs. Thus, we used an antibody that recognises RNA Pol II irrespectively of its phosphorylation status to visualise its accumulation, and RNA-FISH to estimate RNA Pol II activity through the detection of poly-adenylated (poly) mRNA accumulation in the nuclei. Moreover, since some aberrations can be found in genes' expression of intra-species NT embryos, IVF embryos were included in this set of experiments as an additional control group.

We studied the most advanced IVF, NT and iSCNT embryos at 24, 48, 72 and $96 \mathrm{~h}$ after activation. In the nuclei of IVF and NT embryos, RNA Pol II (Fig. 2; Supplementary Figure 2, see section on supplementary data given at the end of this article) and poly(A) RNAs (Fig. 3; Supplementary Figure 3, see section on supplementary data given at the end of this article) were found at all studied stages of early embryo development and labelling intensity clearly increased at 72 and $96 \mathrm{~h}$ post fertilisation/activation in comparison with the earlier time points. Conversely, iSCNT embryos were characterised by low level of RNA Pol II expression and low transcriptional activity in the nuclei starting from the two-cell stage, and both RNA Pol II expression and activity did not increase at the time of EGA (Figs 2 and 3; Supplementary Figures 2 and 3).

\section{Activation of gene expression in iSCNT embryos}

Next, we assessed whether functional transcripts could be generated in iSCNT embryos, despite the low level of RNA Pol II activity by using porcine green fluorescent protein (GFP)-positive foetal fibroblasts (GFP+ cells under the control of the constitutive $P G K$ promoter) as nucleus donor cells for pig-bovine iSCNT embryos. Accumulation of GFP was detected in iSCNT embryos starting from the one-cell stage ( $24 \mathrm{~h}$ after activation), and more than $80 \%$ of pig-bovine iSCNT embryos (Supplementary Table 2) showed accumulation of GFP at day 7 (Supplementary Figure 4, see section on supplementary data given at the end of this article). This indicates that low level of RNA Pol II transcription was present in iSCNT embryos.

Another event associated with RNA Pol II activity but crucially dependent on EGA is the expression of NANOG, a key pluripotency gene (Brevini et al. 2006, Gandolfi et al. 2006). We were unable to detect NANOG mRNA in pig-bovine (Supplementary Figure 5D) iSCNT embryos at any of the developmental stages (2-, 4-, 8- and 16-cell) analysed. These data confirm that no or highly aberrant genome activation takes place at the porcine MET (4-8-cell) or at the bovine MET (8-16 cell).

\section{RNA Pol I activation and nucleolar maturation}

In mammals, the fact that transcriptional activation of class I genes (rRNA) depends on the previous activation of class II genes (mRNA; Shiokawa et al. 1989, 1994) was recently confirmed in bovine (Maddox-Hyttel et al. 2007, Svarcova et al. 2007) and porcine embryos (Maddox-Hyttel et al. 2007). Specifically, RNA Pol I as well as other key nucleolar proteins (Svarcova et al. 2007) are de novo expressed from embryonic genome, and consequently, rRNA gene activation and the associated nucleolus formation have been suggested as
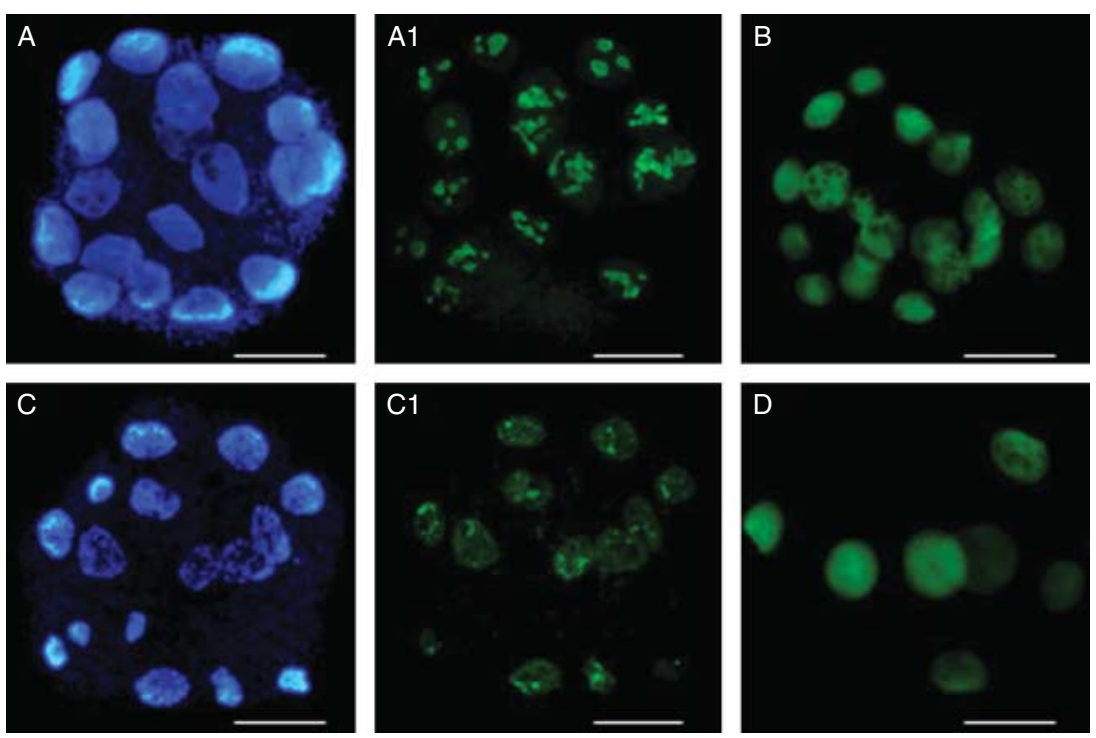

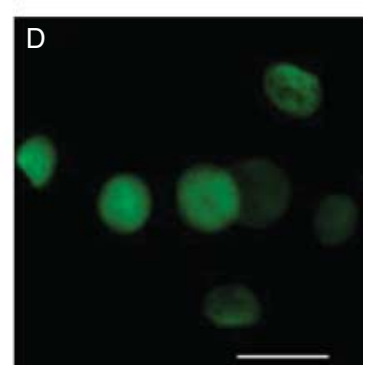

Figure 1 Bovine NT (A, A1, B and D) and pigbovine iSCNT embryos (C and $\mathrm{C} 1$ ) labelled with anti-nucleolin (C23) antibody (A1, B, C1 and D). Bovine NT embryo (A1) and pig-bovine iSCNT embryo (C1) were counterstained with DAPI $(\mathrm{A}$ and $\mathrm{C})$ at $96 \mathrm{~h}$ after activation. DAPI highlighted the presence of (A) homogenously stained nuclei in NT embryo and (C) chromatin condensation in the nuclei of iSCNT embryo. C23 labelling revealed (A1) polygonal mature nucleoli in the nuclei of bovine NT embryo, which (B) disappeared following treatment with $0.2 \mu \mathrm{g} / \mathrm{ml}$ actinomycin $D(A D)$ for $3 h$; (D) the lack of nucleolar formation in bovine NT embryo after $48 \mathrm{~h}$ treatment with $2 \mu \mathrm{g} / \mathrm{ml} \mathrm{AD;}(\mathrm{C} 1)$ the absence of mature nucleoli in pig-bovine iSCNT embryo. Scale bars, $100 \mu \mathrm{m}$. 

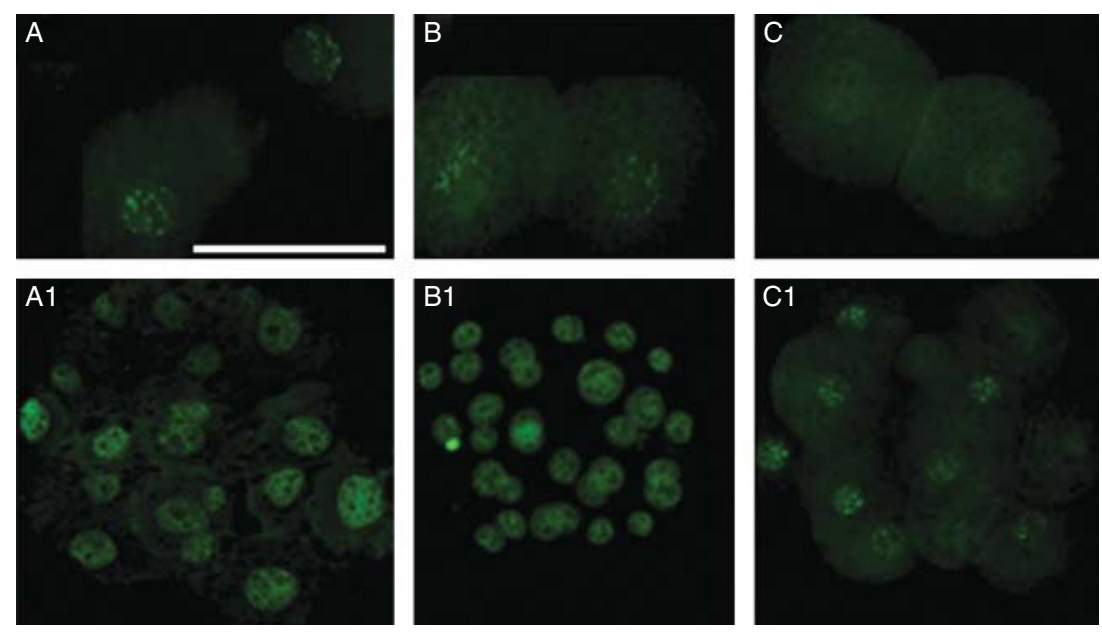

Figure 2 RNA Pol II was visualised with the CTD4H8 antibody that detects both phosphorylated and unphosphorylated RNA Pol II in bovine IVF (A and A1), NT (B and B1) and pig-bovine iSCNT (C and C1) embryos. The embryos were fixed at the two-cell stage $(\mathrm{A}-\mathrm{C})$ and at the most advanced stages at $96 \mathrm{~h}$ after insemination/activation (A1, B1 and C1). CTD4H8 labelling revealed the presence of RNA Pol II in the nuclei of (A) IVF, (B) NT and (C) iSCNT two-cell stage embryos, significant accumulation of RNA Pol II in the nuclei of (A1) IVF and (B1) NT embryos, and (C1) the lack of RNA Pol Il accumulation in iSCNT embryos. Scale bar, $100 \mu \mathrm{m}$. markers of EGA in mammalian embryos (Bjerregaard et al. 2007). Nucleolin is a multifunctional maternally inherited nucleolar protein (Svarcova et al. 2007) engaged in the late processing of rRNA that colocalises with RNA Pol I to nucleoli. We thus used an antibody against nucleolin (C23) to evaluate nucleolus formation in the more advanced NT and iSCNT embryos at $96 \mathrm{~h}$ after activation (Figs 1 and 4). NT embryos were characterised by the presence of intensely labelled polygonal and shell-like mature nucleoli. Conversely, pig-bovine (Fig. 1C1) and bovine-pig (Fig. 4D) iSCNT embryos were characterised by prevailing nucleoplasmic localisation of nucleolin with occasional concentration in faintly stained half-rings or rings in bovine nuclei or in several dots or rings in some porcine nuclei.

This result, together with the data on RNA Pol II and $N A N O G$, suggests that the embryonic genome is not properly activated in iSCNT embryos. To further test this hypothesis, we incubated bovine NT embryos with actinomycin $\mathrm{D}(\mathrm{AD})$ and porcine NT embryos with $\alpha$-amanitin (AA). Long-term (48 h) incubation with AD or AA effectively blocked EGA in NT embryos as indicated by the absence of mature nucleoli (Figs 1D and 4C) and the appearance of nuclei with condensing chromatin in
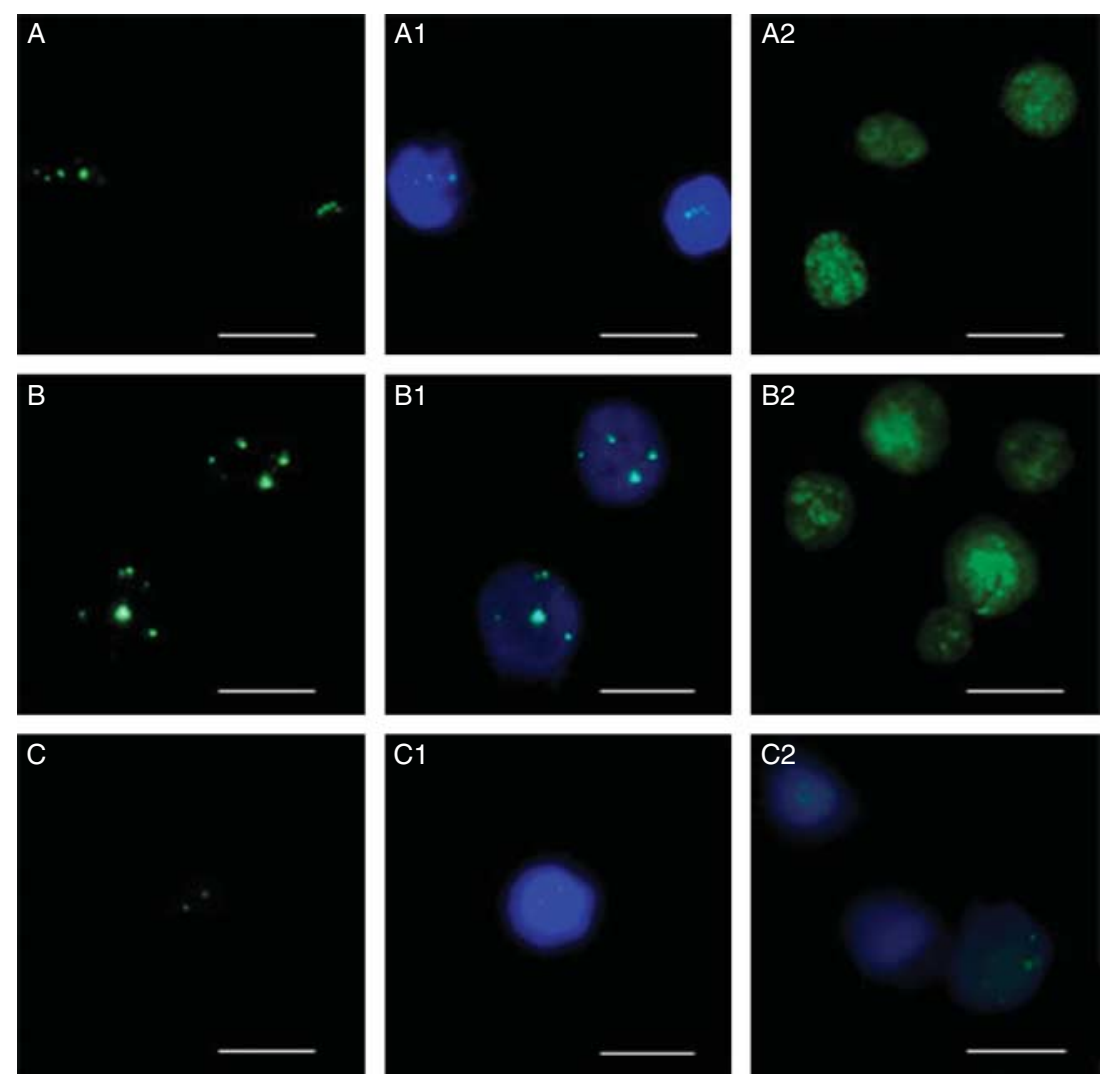
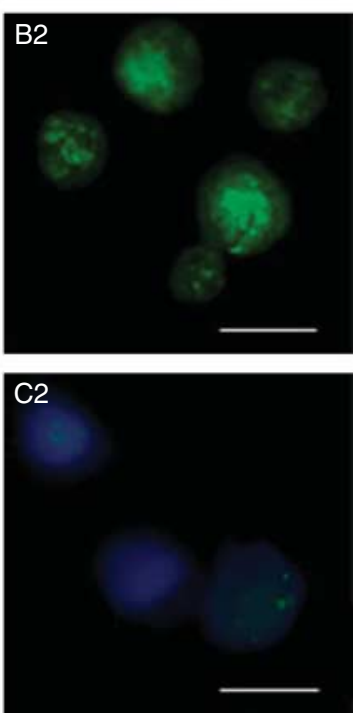

Figure 3 RNA Pol II activity, as determined by the accumulation of polyadenylated transcripts in the nuclei, was assessed by RNA FISH with a fluorescein-labelled oligo dT probe in bovine IVF (A, A1 and A2), NT (B, B1 and B2) and pig-bovine iSCNT (C, C1 and C2) embryos. Embryos were fixed and labelled at the two-cell stage $(\mathrm{A}-\mathrm{C})$ and at the most advanced stages at $96 \mathrm{~h}$ after insemination/activation (A2, B2 and C2). Nuclei were counterstained with DAPI for DNA visualisation. Dot-like labelling of polyadenylated transcripts in the nuclei of two-cell stage (A) IVF, (B) NT and (C) iSCNT embryos and localisation of polyadenylated transcripts in DAPI-stained nuclei of (A1) IVF, (B1) NT and (C1) iSCNT embryos. Accumulation of polyadenylated transcripts in the nuclei of 8-16-cell stage (A2) IVF, (B2) NT embryos and (C2) dot-like labelling in the nuclei of iSCNT embryos. Scale bars, $100 \mu \mathrm{m}$. 

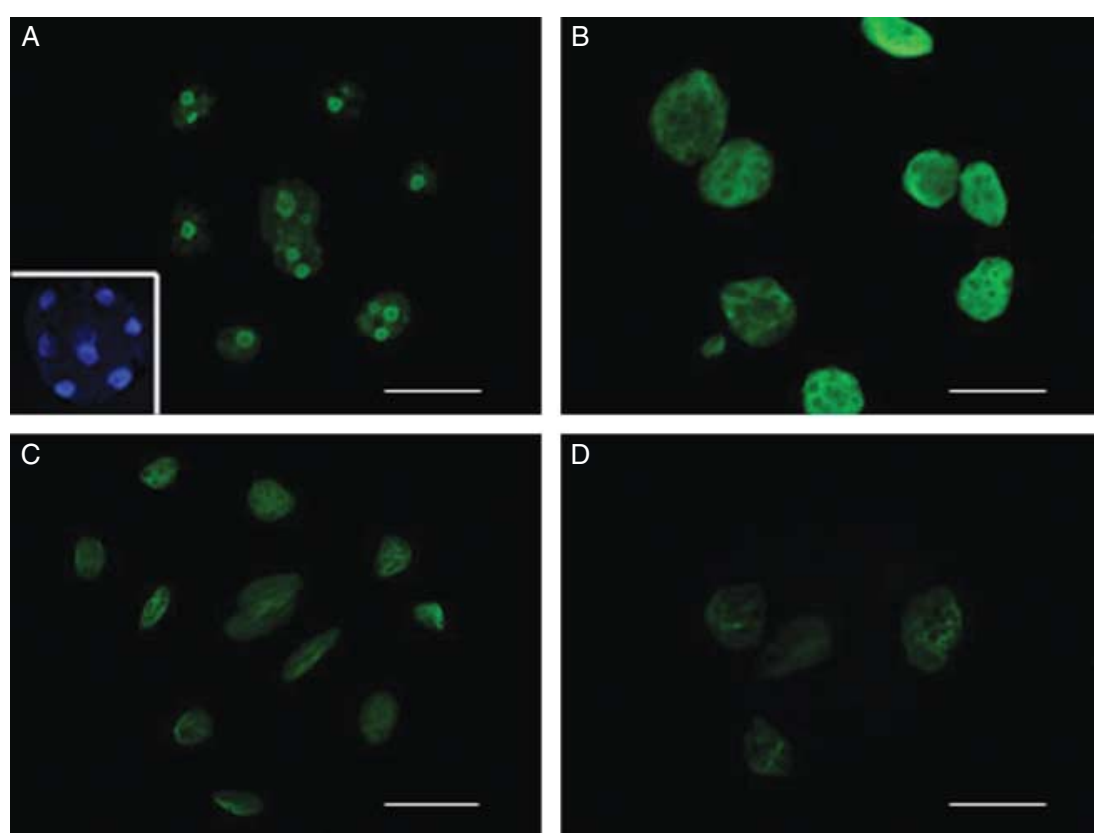

Figure 4 Porcine NT (A-C) and bovine-pig iSCNT (D) embryos labelled with anti-nucleolin (C23) antibody at $96 \mathrm{~h}$ after activation: (A) shell-like mature nucleoli in the nuclei of porcine NT embryo (in the corner the DAPI-staining of the same embryo), (B) disappearance of functional nucleoli from the nuclei of porcine NT embryo after $3 \mathrm{~h}$ treatment with $0.2 \mu \mathrm{g} / \mathrm{ml} \mathrm{AD;}(\mathrm{C})$ the lack of nucleolar formation in porcine NT embryo after $48 \mathrm{~h}$ treatment with $\alpha$-amanitin; (D) the absence of mature nucleoli in bovine-pig iSCNT embryo.

Scale bars, $100 \mu \mathrm{m}$. bovine NT embryos (not shown). Few faintly stained ringlike structures labelled with anti-nucleolin antibody could be found in some nuclei both in bovine and porcine NT embryos. Short incubation $(3 \mathrm{~h}$ ) with $A D$, to block RNA Pol I activity, resulted in complete disappearance of mature nucleoli (Figs 1B and 4B), nucleolin translocation into the nucleoplasm and few weekly antinucleolin-stained rings in some blastomeres. Thus, the formation of mature nucleoli in NT embryos depends on the synthesis of RNA Pol I during EGA and RNA Pol I-guided transcription of rRNA. The similar appearance of iSCNT embryos and AA- or AD-treated NT embryos suggests that in iSCNT embryos, the embryonic genome is not properly activated, RNA Pol I cannot be transcribed and as a result functional nucleoli cannot be formed.

\section{Assessment of mitochondrial changes in NT and iSCNT embryos during development}

Another important issue in iSCNT embryo development is the interaction of the nucleus with complex cytoplasmic organelles like mitochondria. Since mitochondria are involved in a broad range of critical functions (energy supply, cell signalling and apoptosis), inadequate or perturbed mitochondrial function may adversely affect SCNT efficiency (Hiendleder et al. 2005). Moreover, Lee et al. (2002) have shown that the increase in mitochondrial mass depends on cytoplasmic protein synthesis. Thus, changes in the mitochondrial mass in embryos are most probably linked to EGA.

To follow changes in mitochondria, we stained iSCNT and NT embryos with the cationic dye JC- 1 at 48,72 and $96 \mathrm{~h}$ after activation. JC-1 exists in a monomeric form, emitting at $527 \mathrm{~nm}$ (green fluorescence) after excitation at $490 \mathrm{~nm}$. In the cell, it corresponds to the low mitochondrial membrane potential $(<100 \mathrm{mV})$ and characterises relative mitochondrial mass (Mancini et al. 1997). In the presence of high membrane potential $(>140 \mathrm{mV}), \mathrm{JC}-1$ forms so called J-aggregates that are associated with a large shift in emission $(590 \mathrm{~nm}$, red fluorescence). The ratio of red/green fluorescence characterises the inner mitochondrial membrane potential (Reers et al. 1991). We have found that at $48 \mathrm{~h}, \mathrm{NT}$ and iSCNT embryos possessed equal relative mitochondrial mass (Fig. 5) and J-aggregate content (not shown). However, at 72 and $96 \mathrm{~h}$, both parameters were significantly lower in iSCNT embryos than in their NT counterparts $(P<0.05)$. We then asked whether this discrepancy could be linked to the arrest of development and aberrant EGA observed in iSCNT embryos. To this aim, we inhibited genome transcription with $\mathrm{AA}$ in porcine and bovine NT embryos at $48 \mathrm{~h}$ for $24 \mathrm{~h}$, and then stained them with JC- 1 at $72 \mathrm{~h}$. AA treatment led to significantly lower values of mitochondrial mass than in untreated NT embryos confirming that the most likely reason of low mitochondrial parameters in iSCNT embryos is the aberrant EGA.

\section{Discussion}

In the present manuscript, we have tried to characterise the main events of EGA, namely activation of RNA Pol II transcription at the time of MET that should lead to subsequent transcription of RNA Pol I and pluripotency genes. Any serious aberrations of these events cause the developmental failure of the embryos. Our results indicate that the most likely cause of pig-bovine and bovine-pig iSCNT embryos developmental failure is the 


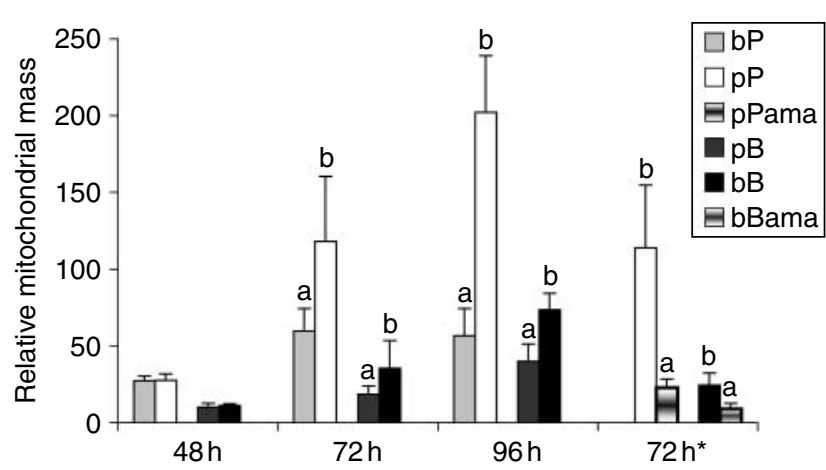

Figure 5 Relative mitochondrial mass $(\mathrm{MM})$ in bovine $\mathrm{NT}(\mathrm{bB})$, porcine NT (pP), pig-bovine iSCNT (pB) and bovine-pig iSCNT (bP) embryos stained with JC-1 at 48, 72 and $96 \mathrm{~h}$ after activation. At $48 \mathrm{~h}, \mathrm{MM}$ of NT and iSCNT embryos derived from the same oocytes was comparable. At 72 and $96 \mathrm{~h}$ after activation, MM values were significantly higher in NT than iSCNT embryos (a, b: $P<0.05)$. Inhibition of RNA Pol II by $\alpha$-amanitin at the time of EGA in porcine (pPama) and bovine (bBama) NT embryos led to significant decrease in MM $(a, b: P<0.05)$ at $72 \mathrm{~h}$ after activation.

absence of EGA or its aberrant implementation due to nucleus-cytoplasm incompatibility.

Differently from other laboratories (Dominko et al. 1999, Uhm et al. 2007, Song et al. 2008), we did not manage to obtain pig-bovine and bovine-pig iSCNT embryos that could develop to the blastocyst stage, whereas intra-species NT proved to work effectively in our hands. Since the efficiency of NT (Boiani et al. 2005, Lagutina et al. 2006) and even more of iSCNT (Liu et al. 2004, Zhao et al. 2006, Sugimura et al. 2009) embryo development crucially depends on embryo culture conditions, we tested both SOFaa and CR1aa, which have been previously reported to support bovine (Galli et al. 2003) and porcine (Lagutina et al. 2006) embryo development and pig-bovine iSCNT blastocyst development (Dominko et al. 1999, Uhm et al. 2007) respectively. No difference was observed, and pig-bovine/ bovine-pig iSCNT embryos were not able to escape the block at the 16-25-cell/four-cell stage, which corresponds to the time of bovine MET (8-16-cell stage; Kanka 2003) and porcine MET (four-cell stage; Tomanek et al. 1989, Freitag et al. 1991, Jarrell et al. 1991). The reasons of such developmental failure in our culture conditions are not clear, but it should not be ascribed to the quality of our in vitro maturation-in vitro culture (IVC) media or to the NT technique used, since several offspring were born following bovine and porcine NT.

The analysis of remodelling of the donor nucleus in the cytoplasm of a recipient oocyte from a different species indicates that the normal pattern of nucleus remodelling was followed as previously reported in different studies on mammalian NT and iSCNT embryos (Tarkowski \& Balakier 1980, Dominko et al. 1999, Arat et al. 2003, Uhm et al. 2007, Lee et al. 2008). Thus, the biochemical mechanism of this process is universal, and it works also in intra-class NT embryos derived from chicken blastodermal cells and rabbit oocytes (Liu et al. 2004).

On the other hand, the cleavage kinetics of NT and iSCNT embryos was comparable only up to $48 \mathrm{~h}$ of IVC, and during the following $24 \mathrm{~h}$, the development of iSCNT embryos was arrested at the MET stage: that is, at the four-cell stage for bovine-pig embryos and at the 8-16-cell stage for pig-bovine embryos. However, pig-bovine iSCNT embryos divided significantly faster than bovine NT control embryos, and many binucleate blastomeres were observed in about $50 \%$ of them. Such accelerated cleavage was reported by Memili \& First (1998) in bovine embryos treated with AA to prevent EGA. This finding together with the observation that our iSCNT embryos stopped dividing at the moment of the oocyte MET suggests that EGA did not take place in our iSCNT embryos.

To confirm this hypothesis, we then assessed RNA Pol II expression and activity. Low level of activity was observed in the nuclei of IVF, NT and iSCNT embryos as early as the two-cell stage. This confirms the data on low-grade transcription during the first three cell cycles in bovine embryos (Barnes \& First 1991, Plante et al. 1994, Hyttel et al. 1996, Viuff et al. 1996, 1998, Memili \& First 1998, Svarcova et al. 2007, Kues et al. 2008) and extends our knowledge about porcine embryos that were considered transcriptionally inactive until late in the third cell cycle, i.e. at the four-cell stage (Tomanek et al. 1989, Freitag et al. 1991, Jarrell et al. 1991). However, during further IVC, iSCNT embryos did not show the important increase in RNA Pol II activity observed in control embryos, which went through normal EGA.

Moreover, $96 \mathrm{~h}$ after activation, iSCNT embryos did not present mature nucleoli. Indeed, immunostaining with an anti-nucleolin antibody revealed faint nucleoplasmic labelling with weakly stained half-rings or rings in bovine nuclei or several dots or rings in some porcine nuclei without formation of mature nucleoli. The same pattern of staining was reported in pig-ovine (Hamilton et al. 2004) and rhesus monkey-bovine iSCNT embryos (Song et al. 2009) that were not able to properly activate the genome and form BL. Inhibition of RNA Pol I transcripition in control NT embryos led to disappearance of nucleolin-labelled mature nucleoli and dispersion of nucleolin into the nucleoplasm. The dispersed nucleoplasmic nucleolin and inability to form nucleoli were also observed in NT embryos after inhibition of EGA as a result of the absence of de novo transcription of RNA Pol I that depends on RNA Pol II activity. Therefore, taking into account the developmental block of iSCNT embryos and the absence of RNA Pol II accumulation and its low activity, we conclude that the failure to form mature nucleoli is the result of the absence of EGA.

We also studied the expression pattern of NANOG (Brevini et al. 2006, Gandolfi et al. 2006), which depends on EGA. Porcine NANOG mRNA was not 
detected even in the best ( $\geq 16$-cell) pig-bovine iSCNT embryos at the time of porcine and bovine EGA as previously reported for chimpanzee-bovine iSCNT embryos (Wang et al. 2009). Comparison of gene expression in 8-16-cell stage human-bovine or human-rabbit embryos and human IVF or NT embryos using single-embryo transcriptome profiling revealed general downregulation of human genes in the bovine and rabbit recipient cytoplasm (Chung et al. 2009). These data and the absence of Alppl2 (eAp), Pou5f1 (Oct4) and $C d h 1$ (e-Cad) expression in mouse embryonic fibroblast (MEF)-bovine iSCNT embryos (Arat et al. 2003, Kim et al. 2004) suggests that bovine ooplasm does not reprogram properly donor nuclei from other species.

On the other hand, we extended our knowledge about the cytoplasm control in iSCNT embryos over xenonucleus genes using constitutive and tissue-specific inducible promoters. The permanent low RNA Pol II activity in iSCNT embryos was sufficient for the observed GFP accumulation in iSCNT embryos derived from fibroblasts that carry the GFP gene under the control of the constitutive $P G K$ promoter, as previously described by Uhm et al. (2007) using GFP controlled by the rat $\beta$-actin promoter. This permanent activity of RNA Pol II is enough to sustain GFP expression in MEF-bovine (Arat et al. 2003) and panda-rabbit iSCNT embryos (Wen et al. 2005), avian feather keratin expression in chicken-rabbit intra-classes iSCNT embryos (Liu et al. 2004), housekeeping gene expression in mouse-bovine iSCNT embryos (Arat et al. 2003, Kim et al. 2004). However, the abnormal pattern of housekeeping genes expression (Arat et al. 2003, Kim et al. 2004, Wang et al. 2009) confirmed the inadequate embryonic genome activity in all tested iSCNT embryos.

On the contrary, our data on the absence of transcription of COL6A1 in iSCNT embryos (Supplementary Figure 5) indicate that bovine cytoplasm can block de novo transcription of a fibroblast-specific gene irrespectively of the species affiliation of the donor nucleus. This agrees with the results by Inoue et al. (2006) and Green et al. (2007) on the silencing of donor cell-specific genes in NT embryos using muscle and hematopoietic cells as nucleus donors and with the statement by Vassena et al. (2007) that the donor genome is markedly silenced by the ooplasm at the one-cell stage of NT embryo development. The silencing of porcine genes in bovine cytoplasm does theoretically prove a high homology of elements controlling gene silencing. Conversely, the expression of avian feather keratin in chicken-rabbit intra-class NT embryos (Liu et al. 2004) as early as in eight-cell embryos is the example of the inability of mammalian ooplasm to correctly recognise avian tissue-specific inducible promoters or silencers.

Another interesting question of iSCNT embryo development is the interaction of the xeno-nucleus with the cytoplasmic mitochondria that have their own DNA and can synthesise RNAs and proteins. It is known that the number of mtDNA copies/embryo is thought to be stable during cleavage until replication begins at an undefined time post-implantation (Aiken et al. 2008) and the total number of mitochondria does not increase during the preimplantation stage of development (Szollosi 1965). However, during early embryo development, mitochondria undergo changes in shape and structure and the number of cristae increases (Betteridge 1988, Van Blerkom 2009). The detailed study (Mtango et al. 2008) of temporal expression of mRNAs related to mitochondrial biogenesis revealed a persistent expression of maternally encoded mRNAs in combination with transcriptional activation and mRNA accumulation around the time of EGA. All proteins involved in mitochondrial biogenesis and functions, currently estimated at $\sim 1500$, are encoded by nuclear DNA, synthesised in the cytosol, and then targeted and imported into mitochondria by specific mechanisms (Cotter et al. 2004, Hiendleder et al. 2005). Lee et al. (2002) demonstrated that the increase in mitochondrial mass does not depend on mtDNA presence or function but on cytoplasmic protein synthesis. Thus, changes of mitochondrial mass in embryos are most probably dependent on EGA. We have found that the relative mitochondrial mass and J-aggregate content were comparable in NT and iSCNT embryos at $48 \mathrm{~h}$ of IVC when only maternally inherited transcripts were available. However, both parameters in iSCNT embryos at $72 \mathrm{~h}$ post-activation were significantly lower than in control NT embryos and resembled those of NT embryos after inhibition of EGA. These results further confirm that EGA is not taking place in iSCNT embryos, and suggest that comparison of the relative mitochondrial mass in iSCNT and control NT embryos at the time of the host oocyte's EGA can serve as an express test to assess genome activation in iSCNT embryos. Another interesting question of the interaction of the xeno-nucleus with the mitochondria in iSCNT embryos that was not studded here is the level of compatibility between nuclear and mitochondrial genomes in iSCNT embryos as the existence of species-specific incompatibility between nuclear and mitochondrial genomes of closely related species has been demonstrated in cybrids of primates (Kenyon \& Moraes 1997, Barrientos et al. 2000) and murids (Dey et al. 2000, McKenzie \& Trounce 2000, McKenzie et al. 2003).

To summarise, our data strongly indicate that bovine and porcine oocytes cannot properly reprogram the genome of each other in iSCNT embryo and activate embryonic genome transcription at the time of MET. The causes of such species incompatibility should be investigated more carefully. One of the reasons might be some specific differences in gene structure. The high homology of mammalian proteins and their coding genes in the case of iSCNT seems not to guarantee proper gene function. For instance, the mouse Pou5f1 promoter correctly activates GFP transcription at the 
time of EGA in bovine NT embryos derived from bovine fibroblasts carrying a mouse Pou5f1 promoter-driven GFP reporter gene (Wuensch et al. 2007), while it does not in porcine NT embryos derived from porcine fibroblasts carrying the same transgene (D Brunetti, personal communication). An aberrant DNA methylation pattern in iSCNT embryos may be another reason. Chen et al. (2004) demonstrated that demethylation of donor repetitive sequences is driven by the recipient ooplasm, and ooplasms from different species have different capabilities to demethylate genes. The results of our study raise the question of inter-species nuclear-cytoplasmic or genomic compatibility. The role of nuclear-cytoplasmic interactions in EGA, gene activation and dependence of the activation of a given gene on the function of others is a large field that needs to be investigated.

\section{Materials and Methods}

\section{Oocyte maturation}

Unless otherwise stated, all chemicals were purchased from Sigma-Aldrich. Oocytes were aspirated from 3 to $8 \mathrm{~mm}$ in diameter ovarian follicles of killed animals. In vitro manipulation was carried out essentially as described previously (Lagutina et al. 2006). Bovine oocytes were matured in TCM199 supplemented with $10 \%$ (v/v) FCS, $1 \mu \mathrm{l} / \mathrm{ml}$ ITS Media Supplement (insulin, transferrin, selenite, Sigma, cat. no. 11884), $1 \mathrm{mM}$ sodium pyruvate, $0.5 \mathrm{mM}$ L-cystein, $10 \mathrm{mM}$ glycine, $100 \mu \mathrm{M} \beta$-mercaptoethanol, gonadotropins $(0.05 \mathrm{IU} / \mathrm{ml}$ FSH and $0.05 \mathrm{IU} / \mathrm{ml} \mathrm{LH}$; Pergovet 75, Serono). Porcine oocytes were matured in DMEM-F12 supplemented with $10 \%(\mathrm{v} / \mathrm{v})$ FCS, $110 \mu \mathrm{g} / \mathrm{ml}$ sodium pyruvate, $75 \mu \mathrm{g} / \mathrm{ml}$ ascorbic acid, $100 \mu \mathrm{g} / \mathrm{ml}$ glutamine, $5 \mu \mathrm{g} / \mathrm{ml}$ myoinositol, $0.4 \mathrm{mM}$ cystine, $0.6 \mathrm{mM}$ cysteamine, ITS Media Supplement $(1 \mu \mathrm{l} / \mathrm{ml})$, gonadotropins $(0.05 \mathrm{IU} / \mathrm{ml} \mathrm{FSH}$ and $0.05 \mathrm{IU} / \mathrm{ml} \mathrm{LH}$; Pergovet 75 , Serono), $100 \mathrm{ng} / \mathrm{ml}$ LONG R3 insulin-like growth factor 1 (IGF1; recombinant IGF analogue), $50 \mathrm{ng} / \mathrm{ml}$ LONG epidermal growth factor (EGF; recombinant EGF analogue) and $5 \mathrm{ng} / \mathrm{ml}$ bovine fibroblast growth factor (bFGF; human recombinant). Bovine and porcine oocytes were cultured at $38.5{ }^{\circ} \mathrm{C}$ in $5 \%$ $\mathrm{CO}_{2}$ in humidified air for 21 and $42 \mathrm{~h}$ respectively.

\section{Production of bovine and porcine IVF embryos}

Bovine IVF embryos were produced as previously described (Lagutina et al. 2002). Porcine IVF embryos: after $42 \mathrm{~h}$ of maturation, oocytes were partially denuded of the cumulus cells and cultured in four-well plates containing $0.3 \mathrm{ml} /$ well of TALP prepared without glucose, supplemented with $1 \mathrm{mg} / \mathrm{ml}$ heparin, $20 \mathrm{mM}$ D-penicillamine, $100 \mathrm{mM}$ hypotaurine, $1 \mathrm{mM}$ adrenaline, and $0.1 \times 10^{6}$ spermatozoa $/ \mathrm{ml}$. Motile spermatozoa were obtained by centrifugation of frozen-thawed semen on a Percoll discontinuous density gradient for $40 \mathrm{~min}$ at $750 \mathrm{~g}$, washed in Ca-free TALP and pelleted by centrifugation for $10 \mathrm{~min}$ at $400 \mathrm{~g}$.

\section{Preparation of donor cells}

Bovine and porcine adult and foetal fibroblasts and porcine foetal GFP-positive fibroblasts (GFP under the control of the $P G K$ promoter) at passages 1-10 were used as donor cells. Fibroblasts were derived from ear biopsies according to standard procedures and cultured in DMEM+TCM 199=1:1 with $10 \%$ FCS. The medium for porcine fibroblasts was supplemented with $5 \mathrm{ng} / \mathrm{ml}$ bFGF (human recombinant). All donor cells were tested for efficient blastocyst development after intra-species NT. Two days before NT, donor cells were passaged, and one day before NT, they were serum starved $(0.5 \%$ FCS $)$ for $24 \mathrm{~h}$.

\section{Nuclear transfer}

NT was carried out essentially as described previously (Lagutina et al. 2006). Briefly, oocytes were denuded of cumulus cells by vortexing in SOF-HEPES in the presence of hyaluronidase, and oocytes with extruded polar bodies were selected. NT embryos were reconstructed following a zona-free method (Oback et al. 2003). After zona pellucida digestion with $0.5 \%$ pronase in PBS, oocytes were washed in SOF-HEPES with $10 \%$ FCS and returned to maturation medium. All further manipulations were performed in SOF-HEPES with $10 \%$ FCS. Zona-free oocytes were exposed to cytocalasin B $(7.5 \mu \mathrm{g} / \mathrm{ml})$ and Hoechst $(5 \mu \mathrm{g} / \mathrm{ml})$ for $5 \mathrm{~min}$. Metaphase chromosomes were removed under u.v. light with a blunt enucleation pipette. Then, each cytoplast was individually washed for few seconds in $300 \mu \mathrm{g} / \mathrm{ml}$ phytohemagglutinin P in PBS and quickly dropped over a single donor cell (Vajta et al. 2003) settled at the bottom of a microdrop of donor cell suspension diluted in SOF-HEPES. Formed cell couples were washed in $0.3 \mathrm{M}$ mannitol $\left(\mathrm{Ca}^{++}\right.$-free, $\left.100 \mu \mathrm{M} \mathrm{Mg}^{++}\right)$solution, fused by double DC-pulse of $1.2 \mathrm{kV} / \mathrm{cm}$ applied for $30 \mu \mathrm{s}$ and returned to maturation medium.

\section{Activation}

\section{Bovine oocytes}

Embryos (2-3 h after fusion) were activated 27-28 $\mathrm{h}$ after the onset of oocyte maturation with $5 \mu \mathrm{M}$ ionomycin in SOF-HEPES for $4 \mathrm{~min}$ followed by 4 -h culture in individual $2-\mu \mathrm{l}$ drops of $2 \mathrm{mM} 6$-dimethylaminopurine in SOF, supplemented with MEM essential and non-essential amino acids and $4 \mathrm{mg} / \mathrm{ml} \mathrm{BSA} \mathrm{(m-SOFaa)}$ at $38.5{ }^{\circ} \mathrm{C}$ in humidified atmosphere of $5 \% \mathrm{CO}_{2}, 5 \% \mathrm{O}_{2}$ and $90 \% \mathrm{~N}_{2}$.

\section{Porcine oocytes}

Embryos (2-3 h after fusion) were activated $48-50 \mathrm{~h}$ after the onset of oocyte maturation by double DC-pulses of $1.2 \mathrm{kV} / \mathrm{cm}$ for $30 \mu \mathrm{s}$ in $0.3 \mathrm{M}$ mannitol solution, containing $1 \mathrm{mM} \mathrm{Ca}^{++}$ (Cheong et al. 2002) and $100 \mu \mathrm{M} \mathrm{Mg}^{++}$, followed by 4-h culture in maturation medium with $5 \mu \mathrm{g} / \mathrm{ml}$ cytochalasin B at $38.5{ }^{\circ} \mathrm{C}$ in humidified atmosphere of $5 \% \mathrm{CO}_{2}, 5 \% \mathrm{O}_{2}$ and $90 \% \mathrm{~N}_{2}$. 


\section{Embryo in vitro culture}

NT and iSCNT embryos were cultured according to the WOW method (Vajta et al. 2000) individually in microwells in $20-\mu l$ drops of $\mathrm{m}$-SOFaa in $5 \% \mathrm{CO}_{2}, 5 \% \mathrm{O}_{2}$ and $90 \% \mathrm{~N}_{2}$ humidified atmosphere at $38.5{ }^{\circ} \mathrm{C}$. Half of the medium was renewed with fresh $\mathrm{m}$-SOFaa at days 4 and 6 (day 0 was the day of NT). Cleavage was assessed $48 \mathrm{~h}$ after activation, the occurrence of BL at day 6 and 7. All experiments were done using three or more replicates (unless otherwise indicated). However, some experiments were done in CR1 medium supplemented with MEM essential and non-essential aminoacids that were claimed to be efficient for the production of iSCNT BL in several species using bovine oocytes (Dominko et al. 1999, Uhm et al. 2007).

To assess the effect of EGA inhibition on the formation of nucleoli, porcine and bovine embryos were cultured in medium supplemented respectively with $25 \mu \mathrm{g} / \mathrm{ml} \mathrm{AA}$ or $0.2 \mu \mathrm{g} / \mathrm{ml}$ AD in the window of time going from 48 to $96 \mathrm{~h}$ of IVC.

To assess the effect of inhibition of RNA Pol I activity on the function of nucleoli, bovine and porcine embryos were cultured in medium supplemented with $0.2 \mu \mathrm{g} / \mathrm{ml} \mathrm{AD}$ for $3 \mathrm{~h}$ starting at $93 \mathrm{~h}$ of IVC.

To evaluate the effect of inhibition of EGA on mitochondria, bovine and porcine NT embryos were cultured in medium supplemented with $25 \mu \mathrm{g} / \mathrm{ml} \mathrm{AA}$ starting at $48 \mathrm{~h}$ and till $72 \mathrm{~h}$ after activation.

\section{RT-PCR}

Unless otherwise indicated, all chemicals were purchased from Invitrogen.

\section{RNA extraction from pig-bovine iSCNT embryos}

Poly $(\mathrm{A})^{+}$RNA was isolated from three separate groups of five iSCNT embryos at the 2-, 4-, 8- and 16-cell stage using the Dynabeads mRNA direct MicroKIT (Dynal-Invitrogen), following the manufacturer's instruction (Supplementary Materials and Methods, see section on supplementary data given at the end of this article).

\section{$R T$}

For each sample, RT was carried out in a total volume of $20 \mu \mathrm{l}$ of reaction mixture using $1 \mu \mathrm{l}$ of Oligo(dT) $)_{12-18}$ primer and $1 \mu \mathrm{l}$ dNTP Mix (10 mM each). RNA was denatured at $65^{\circ} \mathrm{C}$ for $5 \mathrm{~min}$, then $4 \mu \mathrm{l}$ of first-strand buffer $(250 \mathrm{mM}$ Tris- $\mathrm{HCl} \mathrm{pH} 8.3$, $375 \mathrm{mM} \mathrm{KCl}$ and $15 \mathrm{mM} \mathrm{MgCl}_{2}$ ), $1.5 \mu \mathrm{l} 50 \mathrm{mM} \mathrm{MgCl}_{2}, 2 \mu \mathrm{l}$ of $0.1 \mathrm{M}$ dithiothreitol and $1 \mu \mathrm{l}$ of RNaseOUT Recombinant Ribonuclease Inhibitor $(40 \mathrm{U} / \mu \mathrm{l})$ were added. RT was performed with $200 \mathrm{U}(1 \mu \mathrm{l})$ Superscript II RT for $1 \mathrm{~h}$ at $42{ }^{\circ} \mathrm{C}$, followed by a denaturation step at $70{ }^{\circ} \mathrm{C}$ for 15 min. Tubes without RNA or RT were prepared as negative controls (data not shown).

\section{PCR}

Accession number, primer sequences, annealing temperature, amplification product sizes and number of amplification cycles for each gene are presented in Supplementary Table 4, see section on supplementary data given at the end of this article. Rabbit globin mRNA was used as exogenous standard to normalise reactions for the amount of RNA in each sample. PCR amplification was performed with CDNA concentrations equivalent to one embryo from different pools of iSCNT embryos. The reaction mix consisted of $11 \mu \mathrm{l}$ of $50 \mathrm{mM} \mathrm{MgCl}_{2}$, $0.3 \mu \mathrm{l}$ of Taq DNA polymerase $(5 \mathrm{U} / \mu \mathrm{l}), 2 \mu \mathrm{l}$ of $10 \times$ PCR buffer (200 mM Tris-HCl pH 8.4, $500 \mathrm{mM} \mathrm{KCl}), 1 \mu \mathrm{l}$ NTP Mix (10 mM each), $1 \mu \mathrm{l}(100 \mathrm{pmol})$ of each sequence-specific primer and sterile water up to $20 \mu \mathrm{l}$. Amplifications were carried out in an automated thermal cycler (iCycler, Bio-Rad). To confirm the identity of the RT-PCR fragments, amplification products from each primer pair were separated by gel electrophoresis in 2\% agarose gels, purified using Spin-X centrifuge tube filters (Corning, Milan, Italy; Sigma-Aldrich), sequenced (SEQLAB, Gottingen, Germany) and aligned using Clustal W 1.82 (EMBL-EBI service).

\section{Immunocytochemistry}

IVF, NT and iSCNT embryos at 24, 48, 72 and $96 \mathrm{~h}$ after activation were fixed in $4 \%$ paraformaldehyde in PBS with $0.1 \%$ Triton $\mathrm{X}-100$ at $4{ }^{\circ} \mathrm{C}$ for $3 \mathrm{~h}$ and subsequently stained with antibodies against nucleolin (C23, an indirect marker of RNA Pol I activity; Santa Cruz Biotechnology Inc., Santa Cruz, CA, USA, sc-8031) and RNA Pol II (CTD4H8; Covance Research Products Inc., Princeton, NJ, USA) overnight. Embryos were washed in PBS/BSA and incubated with the secondary antibody conjugated with FITC (Santa Cruz Biotechnology) at room temperature for $2 \mathrm{~h}$, washed in PBS/BSA and mounted in Cytifluor with DAPI.

\section{FISH}

RNA Pol II activity was assessed in IVF, NT and iSCNT embryos at 24, 48, 72 and $96 \mathrm{~h}$ after activation by detection of polyadenylated transcripts in the nuclei using RNA FISH with a fluorescein-labelled oligo dT probe (Sigma). This probe was 45 bases long with fluorescein inserted every ten position. The method was based on the protocol by Tam et al. (2002) with slight modifications for embryos (Supplementary Materials and Methods).

\section{Analysis of GFP reporter gene expression}

To visualise RNA Pol II activity in pig-bovine iSCNT embryos derived from porcine foetal fibroblasts that carry the GFP reporter gene under the control of the constitutive promoter $P G K$, we estimated the expression of the GFP gene $24 \mathrm{~h}$ after activation and at day 7 under a fluorescence microscope using a standard FITC filter set.

\section{Assessment of mitochondrial changes}

We used JC-1 fluorescent dye (Invitrogen) that accumulates in mitochondria to assess the behaviour of mitochondria in bovine and porcine NT and iSCNT embryos. Embryos at 48, 72 and $96 \mathrm{~h}$ after activation were stained with $2 \mu \mathrm{M} \mathrm{JC}-1$ in SOF-HEPES with $10 \%$ FCS at $37{ }^{\circ} \mathrm{C}$ for $1 \mathrm{~h}$. Images were collected using a double FITC/Rodamine filter. Both red and 
green fluorescence emissions from the area of the embryo where dye distribution artefacts have been removed were analysed with Adobe Photoshop Elements 2. The data were presented as a mean fluorescence intensity of the embryo. In total, not less than 20 embryos per every group/time point were analysed in three replicates.

\section{Nucleus remodelling, number of nuclei and cells}

NT and iSCNT embryos $1 \mathrm{~h}$ after fusion and 3, 48, 72 and $96 \mathrm{~h}$ after activation were stained with Hoechst 33342 to estimate morphology, number and distribution of nuclei.

\section{ApoAlert Annexin V staining}

Staining of NT and iSCNT embryos at $96 \mathrm{~h}$ after activation was performed according to the manufacturer's instructions (Clontech Laboratories, Inc). Images were analysed using FITC and Rodamine filters.

\section{Images}

Embryos were viewed with the fluorescence microscope Nikon Eclipse 80i using FITC, Rodamine or dual filter set for FITC/Rodamine, and images were collected using a DS Camera Head DS-5M with DS Camera Control Unit DS-L1 (Nikon Instruments, Milan, Italy).

\section{Statistical analysis}

Differences between the experimental groups were verified using Student's $t$-test and the $\chi^{2}$ test. A value of $P<0.05$ was considered significant.

\section{Supplementary data}

This is linked to the online version of the paper at http://dx.doi. org/10.1530/REP-09-0578.

\section{Declaration of interest}

The authors declare that there is no conflict of interest that could be perceived as prejudicing the impartiality of the research reported.

\section{Funding}

This work was supported as part of the European Science Foundation EUROCORES Programme EuroSTELLS by funds from the European Commission (contract no. ERAS-CT-2003980409), by the Xenome (LSHB-CT-2006-037377), the Plurisys (no. 223485), the TECLA project from MIUR, the NOBEL projects from Fondazione Cariplo and by the Ministry of Agriculture of The Czech Republic (grant no. MZE 0002701404).

\section{Acknowledgements}

The technical support of Gabriella Crotti, Paola Turini and Massimo lazzi is greatly acknowledged.

\section{References}

Aiken CEM, Cindrova-Davies T \& Johnson MH 2008 Variations in mouse mitochondrial DNA copy number from fertilization to birth are associated with oxidative stress. Reproductive Biomedicine Online 17 806-813.

Arat S, Rzucidlo SJ \& Stice SL 2003 Gene expression and in vitro development of inter-species nuclear transfer embryos. Molecular Reproduction and Development 66 334-342.

Barnes FL \& First NL 1991 Embryonic transcription in in vitro cultured bovine embryos. Molecular Reproduction and Development 29 117-123.

Barrientos A, Muller S, Dey R, Wienberg J \& Moraes CT 2000 Cytochrome $C$ oxidase assembly in primates is sensitive to small evolutionary variations in amino acid sequence. Molecular Biology and Evolution 17 1508-1519.

Betteridge KJ 1988 The anatomy and physiology of pre-attachment bovine embryos. Theriogenology 29 155-187.

Bjerregaard B, Pedersen HG, Jakobsen AS, Rickords LF, Lai L, Cheong HT, Samuel M, Prather RS, Strejcek F, Rasmussen ZR et al. 2007 Activation of ribosomal RNA genes in porcine embryos produced in vitro or by somatic cell nuclear transfer. Molecular Reproduction and Development 74 35-41.

Boiani M, Gentile L, Gambles VV, Cavaleri F, Redi CA \& Scholer HR 2005 Variable reprogramming of the pluripotent stem cell marker Oct4 in mouse clones: distinct developmental potentials in different culture environments. Stem Cells 23 1089-1104.

Brevini T, Antonini S, Cillo F, Lagutina I, Colleoni S, Lazzari G, Galli C \& Gandolfi F 2006 Maternal to embryonic transition following nuclear transfer or parthenogenetic activation. Reproduction, Fertility, and Development 18 121. Abstract 25.

Chang KH, Lim JM, Kang SK, Lee BC, Moon SY \& Hwang WS 2003 Blastocyst formation, karyotype, and mitochondrial DNA of interspecies embryos derived from nuclear transfer of human cord fibroblasts into enucleated bovine oocytes. Fertility and Sterility $\mathbf{8 0}$ 1380-1387.

Chen T, Zhang YL, Jiang Y, Liu SZ, Schatten H, Chen DY \& Sun QY 2004 The DNA methylation events in normal and cloned rabbit embryos. FEBS Letters 578 69-72.

Cheong HT, Park KW, Im GS, Lai L, Sun QY, Day BN \& Prather RS 2002 Effect of elevated $\mathrm{Ca}(2+)$ concentration in fusion/activation medium on the fusion and development of porcine fetal fibroblast nuclear transfer embryos. Molecular Reproduction and Development 61 488-492.

Chung Y, Bishop CE, Treff NR, Walker SJ, Sandler VM, Becker S, Klimanskaya I, Wun WS, Dunn R, Hall RM et al. 2009 Reprogramming of human somatic cells using human and animal oocytes. Cloning and Stem Cells 11 213-223.

Cotter D, Guda P, Fahy E \& Subramaniam S 2004 MitoProteome: mitochondrial protein sequence database and annotation system. Nucleic Acids Research 32 D463-D467.

Dey R, Barrientos A \& Moraes CT 2000 Functional constraints of nuclear-mitochondrial DNA interactions in xenomitochondrial rodent cell lines. Journal of Biological Chemistry 275 31520-31527.

Dominko T, Mitalipova M, Haley B, Beyhan Z, Memili E, McKusick B \& First NL 1999 Bovine oocyte cytoplasm supports development of embryos produced by nuclear transfer of somatic cell nuclei from various mammalian species. Biology of Reproduction 60 1496-1502.

Freitag M, Dopke HH, Niemann H \& Elsaesser F $1991{ }^{3} \mathrm{H}$-uridine incorporation in early porcine embryos. Molecular Reproduction and Development 29 124-128.

Galli C, Duchi R, Crotti G, Turini P, Ponderato N, Colleoni S, Lagutina I \& Lazzari G 2003 Bovine embryo technologies. Theriogenology $\mathbf{5 9}$ 599-616. 
Gandolfi F, Cillo F, Antonini S, Colleoni S, Lagutina I, Lazzari G, Galli C \& Brevini TAL 2006 Expression pattern of Nanog and Par3 genes in in vitro derived bovine embryos. Reproduction, Fertility, and Development 18 231 (abstract).

Gomez MC, Pope CE, Giraldo A, Lyons LA, Harris RF, King AL, Cole A, Godke RA \& Dresser BL 2004 Birth of African wildcat cloned kittens born from domestic cats. Cloning and Stem Cells 6 247-258.

Gomez MC, Pope CE, Kutner RH, Ricks DM, Lyons LA, Ruhe M, Dumas C, Lyons J, López M, Dresser BL et al. 2008 Nuclear transfer of sand cat cells into enucleated domestic cat oocytes is affected by cryopreservation of donor cells. Cloning and Stem Cells 10 469-483.

Green AL, Wells DN \& Oback B 2007 Cattle cloned from increasingly differentiated muscle cells. Biology of Reproduction 77 395-406.

Hamilton HM, Peura TT, Laurincik J, Walker SK, Maddocks S \& MaddoxHyttel P 2004 Ovine ooplasm directs initial nucleolar assembly in embryos cloned from ovine, bovine, and porcine cells. Molecular Reproduction and Development 69 117-125.

Hashem MA, Bhandari DP, Kang SK \& Lee BC 2007 Cell cycle analysis and interspecies nuclear transfer of in vitro cultured skin fibroblasts of the Siberian tiger (Panthera tigris altaica). Molecular Reproduction and Development 74 403-411.

Heix J, Zomerdijk JC, Ravanpay A, Tjian R \& Grummt I 1997 Cloning of murine RNA polymerase I-specific TAF factors: conserved interactions between the subunits of the species-specific transcription initiation factor TIF-IB/SL1. PNAS 94 1733-1738.

Hiendleder S, Zakhartchenko V \& Wolf E 2005 Mitochondria and the success of somatic cell nuclear transfer cloning: from nuclearmitochondrial interactions to mitochondrial complementation and mitochondrial DNA recombination. Reproduction, Fertility, and Development 17 69-83.

Hyttel P, Viuff D, Avery B, Laurincik J \& Greve T 1996 Transcription and cell cycle-dependent development of intranuclear bodies and granules in two-cell bovine embryos. Journal of Reproduction and Fertility 108 263-270.

Illmensee K, Levanduski M \& Zavos PM 2006 Evaluation of the embryonic preimplantation potential of human adult somatic cells via an embryo interspecies bioassay using bovine oocytes. Fertility and Sterility $\mathbf{8 5}$ (Supplement 1) 1248-1260.

Inoue K, Ogonuki N, Miki H, Hirose M, Noda S, Kim JM, Aoki F, Miyoshi H \& Ogura A 2006 Inefficient reprogramming of the hematopoietic stem cell genome following nuclear transfer. Journal of Cell Science 119 1985-1991.

Jarrell VL, Day BN \& Prather RS 1991 The transition from maternal to zygotic control of development occurs during the 4-cell stage in the domestic pig, Sus scrofa: quantitative and qualitative aspects of protein synthesis. Biology of Reproduction 44 62-68.

Jian-Quan C, Juan C, Xu-Jun X, Guo-Hui L, Si-Guo L, Hong-Ying S, You-Bing W \& Guo-Xiang C 2007 Effect of cytoplast on the development of inter-subspecies nuclear transfer reconstructed goat embryo. Molecular Reproduction and Development 74 568-573.

Kanka J 2003 Gene expression and chromatin structure in the pre-implantation embryo. Theriogenology 59 3-19.

Kenyon L \& Moraes CT 1997 Expanding the functional human mitochondrial DNA database by the establishment of primate xenomitochondrial cybrids. PNAS 94 9131-9135.

Kim N-H, Shin MR \& Park SH 2004 Bovine oocyte cytoplasm supports nuclear remodeling but not reprogramming of murine fibroblasts. Reproduction, Fertility, and Development 16 145-146. Abstract 47.

Kim MK, Jang G, Oh HJ, Yuda F, Kim HJ, Hwang WS, Hossein MS, Kim JJ, Shin NS, Kang SK et al. 2007 Endangered wolves cloned from adult somatic cells. Cloning and Stem Cells 9 130-137.

Kues WA, Sudheer S, Herrmann D, Carnwath JW, Havlicek V, Besenfelder U, Lehrach H, Adjaye J \& Niemann H 2008 Genomewide expression profiling reveals distinct clusters of transcriptional regulation during bovine preimplantation development in vivo. PNAS 105 19768-19773.

Lagutina I, Ponderato N, Lazzari G \& Galli C 2002 Kinetics of oocyte maturation and subsequent development of IVF, parthenogenetic, and NT bovine embryos after meiotic inhibition with roscovitine. Cloning and Stem Cells 4 113-119.

Lagutina I, Lazzari G \& Galli C 2006 Birth of cloned pigs from zona-free nuclear transfer blastocysts developed in vitro before transfer. Cloning and Stem Cells 8 283-293.
Lanza RP, Cibelli JB, Diaz F, Moraes CT, Farin PW, Farin CE, Hammer CJ, West MD \& Damiani P 2000 Cloning of an endangered species (Bos gaurus) using interspecies nuclear transfer. Cloning 2 79-90.

Lee HC, Yin PH, Chi CW \& Wei YH 2002 Increase in mitochondrial mass in human fibroblasts under oxidative stress and during replicative cell senescence. Journal of Biomedical Science 9 517-526.

Lee E, Kim JH, Park SM, Jeong YI, Lee JY, Park SW, Choi J, Kim HS, Jeong YW, Kim S et al. 2008 The analysis of chromatin remodeling and the staining for DNA methylation and histone acetylation do not provide definitive indicators of the developmental ability of inter-species cloned embryos. Animal Reproduction Science 105 438-450.

Li Y, Li S, Dai Y, Du W, Zhao C, Wang L, Wang H, Li R, Liu Y, Wan R et al. 2007 Nuclear reprogramming in embryos generated by the transfer of yak (Bos grunniens) nuclei into bovine oocytes and comparison with bovine-bovine SCNT and bovine IVF embryos. Theriogenology 67 1331-1338.

Li F, Cao H, Zhang Q, Li R, Chen X, Fang Z, Xue K, Chen da Y \& Sheng HZ 2008 Activation of human embryonic gene expression in cytoplasmic hybrid embryos constructed between bovine oocytes and human fibroblasts. Cloning and Stem Cells 10 297-305.

Liu SZ, Zhou ZM, Chen T, Zhang YL, Wen DC, Kou ZH, Li ZD, Sun QY \& Chen DY 2004 Blastocysts produced by nuclear transfer between chicken blastodermal cells and rabbit oocytes. Molecular Reproduction and Development 69 296-302.

Loi P, Ptak G, Barboni B, Fulka J Jr, Cappai P \& Clinton M 2001 Genetic rescue of an endangered mammal by cross-species nuclear transfer using post-mortem somatic cells. Nature Biotechnology 19 962-964.

Lorthongpanich C, Laowtammathron C, Chan AW, Ketudat-Cairns M \& Parnpai R 2008 Development of interspecies cloned monkey embryos reconstructed with bovine enucleated oocytes. Journal of Reproduction and Development 54 306-313.

Maddox-Hyttel P, Svarcova O \& Laurincik J 2007 Ribosomal RNA and nucleolar proteins from the oocyte are to some degree used for embryonic nucleolar formation in cattle and pig. Theriogenology 68 (Supplement 1) S63-S70.

Mancini M, Anderson BO, Caldwell E, Sedghinasab M, Paty PB \& Hockenbery DM 1997 Mitochondrial proliferation and paradoxical membrane depolarization during terminal differentiation and apoptosis in a human colon carcinoma cell line. Journal of Cell Biology 138 449-469.

Mastromonaco GF, Favetta LA, Smith LC, Filion F \& King WA 2007 The influence of nuclear content on developmental competence of gaur $X$ cattle hybrid in vitro fertilized and somatic cell nuclear transfer embryos. Biology of Reproduction 76 514-523.

McKenzie M \& Trounce I 2000 Expression of Rattus norvegicus mtDNA in Mus musculus cells results in multiple respiratory chain defects. Journal of Biological Chemistry 275 31514-31519.

McKenzie M, Chiotis M, Pinkert CA \& Trounce IA 2003 Functional respiratory chain analyses in murid xenomitochondrial cybrids expose coevolutionary constraints of cytochrome $b$ and nuclear subunits of complex III. Molecular Biology and Evolution 20 1117-1124.

Memili E \& First NL 1998 Developmental changes in RNA polymerase II in bovine oocytes, early embryos, and effect of $\alpha$-amanitin on embryo development. Molecular Reproduction and Development 51 381-389.

Minami N, Suzuki T \& Tsukamoto S 2007 Zygotic gene activation and maternal factors in mammals. Journal of Reproduction and Development $53707-715$.

Mtango NR, Harvey AJ, Latham KE \& Brenner CA 2008 Molecular control of mitochondrial function in developing rhesus monkey oocytes and preimplantation-stage embryos. Reproduction, Fertility, and Development 20 846-859.

Oback B, Wiersema AT, Gaynor P, Laible G, Tucker FC, Oliver JE, Miller AL, Troskie HE, Wilson KL, Forsyth JT et al. 2003 Cloned cattle derived from a novel zona-free embryo reconstruction system. Cloning and Stem Cells 5 3-12.

Plante L, Plante C, Shepherd DL \& King WA 1994 Cleavage and ${ }^{3} \mathrm{H}$-uridine incorporation in bovine embryos of high in vitro developmental potential. Molecular Reproduction and Development 39 375-383.

Reers M, Smith TW \& Chen LB 1991 J-aggregate formation of a carbocyanine as a quantitative fluorescent indicator of membrane potential. Biochemistry 30 4480-4486. 
Schultz RM 1993 Regulation of zygotic gene activation in the mouse. BioEssays 15 531-538.

Shi LH, Miao YL, Ouyang YC, Huang JC, Lei ZL, Yang JW, Han ZM, Song XF, Sun QY \& Chen DY 2008 Trichostatin A (TSA) improves the development of rabbit-rabbit intraspecies cloned embryos, but not rabbit-human interspecies cloned embryos. Developmental Dynamics 237 640-648.

Shiokawa K, Misumi Y, Tashiro K, Nakakura N, Yamana K \& Oh-uchida M 1989 Changes in the patterns of RNA synthesis in early embryogenesis of Xenopus laevis. Cell Differentiation and Development 28 17-25.

Shiokawa K, Kurashima R \& Shinga J 1994 Temporal control of gene expression from endogenous and exogenously-introduced DNAs in early embryogenesis of Xenopus laevis. International Journal of Developmental Biology 38 249-255.

Song BS, Kim JS, Jin XL, Lee YY, Cho YJ, Kim CH, Lee KK \& Koo DB 2008 Development of interspecies cloned embryos using somatic cells from various species and bovine cytoplacts. Reproduction, Fertility, and Development 20 109. Abstract 56.

Song BS, Lee SH, Kim SU, Kim JS, Park JS, Kim CH, Chang KT, Han YM, Lee KK, Lee DS et al. 2009 Nucleologenesis and embryonic genome activation are defective in interspecies cloned embryos between bovine ooplasm and rhesus monkey somatic cells. BMC Developmental Biology 944.

Sugimura S, Narita K, Yamashiro H, Sugawara A, Shoji T, Terashita $Y$, Nishimori K, Konno T, Yoshida M \& Sato E 2009 Interspecies somatic cell nucleus transfer with porcine oocytes as recipients: a novel bioassay system for assessing the competence of canine somatic cells to develop into embryos. Theriogenology 72 549-559.

Svarcova O, Laurincik J, Avery B, Mlyncek M, Niemann H \& MaddoxHyttel P 2007 Nucleolar development and allocation of key nucleolar proteins require de novo transcription in bovine embryos. Molecular Reproduction and Development $\mathbf{7 4}$ 1428-1435.

Szollosi DG 1965 The fate of sperm middle-piece mitochondria in the rat egg. Journal of Experimental Zoology 159 367-378.

Tam R, Shopland LS, Johnson CV, McNeil JA \& Lawrence JB 2002 Application of FISH for visualising gene expression and nuclear architecture. In FISH - Practical Approach. Eds BG Beatty, S Mai \& JA Squire. Oxford: Oxford University Press.

Tarkowski AK \& Balakier H 1980 Nucleo-cytoplasmic interactions in cell hybrids between mouse oocytes, blastomeres and somatic cells. Journal of Embryology and Experimental Morphology 55 319-330.

Tomanek M, Kopecny V \& Kanka J 1989 Genome reactivation in developing early pig embryos: an ultrastructural and autoradiographic analysis. Anatomy and Embryology 180 309-316.

Tsunoda Y, Tokunaga T, Imai H \& Uchida T 1989 Nuclear transplantation of male primordial germ cells in the mouse. Development 107 407-411.

Uhm SJ, Gupta MK, Kim T \& Lee HT 2007 Expression of enhanced green fluorescent protein in porcine- and bovine-cloned embryos following interspecies somatic cell nuclear transfer of fibroblasts transfected by retrovirus vector. Molecular Reproduction and Development $\mathbf{7 4}$ $1538-1547$.
Vajta G, Peura TT, Holm P, Paldi A, Greve T, Trounson AO \& Callesen H 2000 New method for culture of zona-included or zona-free embryos: the Well of the Well (WOW) system. Molecular Reproduction and Development 55 256-264.

Vajta G, Lewis IM, Trounson AO, Purup S, Maddox-Hyttel P, Schmidt M, Pedersen HG, Greve T \& Callesen H 2003 Handmade somatic cell cloning in cattle: analysis of factors contributing to high efficiency in vitro. Biology of Reproduction 68 571-578.

Van Blerkom J 2009 Mitochondria in early mammalian development. Seminars in Cell and Developmental Biology 20 354-364.

Vassena R, Han Z, Gao S, Baldwin DA, Schultz RM \& Latham KE 2007 Tough beginnings: alterations in the transcriptome of cloned embryos during the first two cell cycles. Developmental Biology 304 75-89.

Viuff D, Avery B, Greve T, King WA \& Hyttel P 1996 Transcriptional activity in in vitro produced bovine two- and four-cell embryos. Molecular Reproduction and Development 43 171-179.

Viuff D, Hyttel P, Avery B, Vajta G, Greve T, Callesen H \& Thomsen PD 1998 Ribosomal ribonucleic acid is transcribed at the 4-cell stage in in vitro-produced bovine embryos. Biology of Reproduction $\mathbf{5 9}$ 626-631.

Wang K, Beyhan Z, Rodriguez RM, Ross PJ, lager AE, Kaiser GG, Chen Y \& Cibelli JB 2009 Bovine ooplasm partially remodels primate somatic nuclei following somatic cell nuclear transfer. Cloning and Stem Cells $\mathbf{1 1}$ 187-202.

Wen DC, Bi CM, Xu Y, Yang CX, Zhu ZY, Sun QY \& Chen DY 2005 Hybrid embryos produced by transferring panda or cat somatic nuclei into rabbit MII oocytes can develop to blastocyst in vitro. Journal of Experimental Zoology. Part A, Comparative Experimental Biology 303 689-697.

Wuensch A, Habermann FA, Kurosaka S, Klose R, Zakhartchenko V, Reichenbach HD, Sinowatz F, McLaughlin KJ \& Wolf E 2007 Quantitative monitoring of pluripotency gene activation after somatic cloning in cattle. Biology of Reproduction 76 983-991.

Yin XJ, Lee YH, Jin JY, Kim NH \& Kong IK 2006 Nuclear and microtubule remodeling and in vitro development of nuclear transferred cat oocytes with skin fibroblasts of the domestic cat (Felis silvestris catus) and leopard cat (Prionailurus bengalensis). Animal Reproduction Science 95 307-315.

Zhao ZJ, Ouyang YC, Nan CL, Lei ZL, Song XF, Sun QY \& Chen DY 2006 Rabbit oocyte cytoplasm supports development of nuclear transfer embryos derived from the somatic cells of the camel and Tibetan antelope. Journal of Reproduction and Development 52 449-459.

Received 31 December 2009

First decision 2 February 2010

Revised manuscript received 20 May 2010

Accepted 4 June 2010 